Plant Biosystems - An International Journal Dealing with all Aspects of Plant Biology

Official Journal of the Societa Botanica Italiana

ISSN: (Print) (Online) Journal homepage: https://www.tandfonline.com/loi/tplb20

\title{
Polyploidy in Odontarrhena bertolonii (Brassicaceae) in relation to seed germination performance and plant phenotype, with taxonomic implications
}

\section{Federico Selvi \& Laura Vivona}

To cite this article: Federico Selvi \& Laura Vivona (2021): Polyploidy in Odontarrhena bertolonii (Brassicaceae) in relation to seed germination performance and plant phenotype, with taxonomic implications, Plant Biosystems - An International Journal Dealing with all Aspects of Plant Biology, DOI: $10.1080 / 11263504.2021 .1985001$

To link to this article: https://doi.org/10.1080/11263504.2021.1985001

\section{曲 Published online: 13 Oct 2021.}

Submit your article to this journal

\section{ЏIII Article views: 5}

Q View related articles $₫$

View Crossmark data $\asymp$ 


\title{
Polyploidy in Odontarrhena bertolonii (Brassicaceae) in relation to seed germination performance and plant phenotype, with taxonomic implications
}

\author{
Federico Selvi (D) and Laura Vivona \\ Department of Agriculture, Food, Environment and Forestry, Laboratories of Botany, Università di Firenze, Firenze, Italy
}

\begin{abstract}
Odontarrhena bertolonii is an endemic serpentine species of Tuscany and Liguria and a model system for nickel-hyperaccumulation research in plants. Phenotypic, genetic and karyological variability between populations was previously detected, but existence and distribution of cytotypes was unknown. Accordingly, we examined ploidy level in eight populations from the species range and tested the polyploid fitness hypothesis by analysing relationships with plant phenotype and seed germination capacity. Accessions from central-western Tuscany and Liguria resulted diploid, while those from the upper Tiber valley were tetraploid. Autopolyploidy via unreduced gametes is likely the mechanism for the origin of tetraploid plants. Size and mass were higher in tetraploid seeds, which germinated faster and to higher percentages than diploid ones. Tetraploid plants were more robust and taller, with more richly branched inflorescences. Silicle shape and size did not differ, but style was longer in tetraploids and seeds had a larger wing. Overall, these results supported a higher fitness in polyploids. Multivariate analysis showed continuous variation but consistent differentiation between diploid and tetraploid accessions. Taxonomically, the tetraploid populations at the eastern limit of the species range in the upper Tiber valley can be referred to a new subspecies, here described as $O$. bertolonii subsp. cesalpina.
\end{abstract}

ARTICLE HISTORY

Received 5 March 2021

Accepted 21 September 2021

\section{KEYWORDS}

Alyssum;

metallophytes;

morphometrics;

$\mathrm{Ni}$-accumulating plants;

polyploid fitness;

serpentine endemics;

taxonomy

\section{Introduction}

Odontarrhena bertolonii (Desv.) Jord. \& Fourr. is one of the most emblematic species of the Tusco-Ligurian endemic flora of serpentine soils, and one of the most characteristic component of the corresponding vegetation (Chiarucci et al. 1995; Chiarucci 2003; Selvi 2007; Pignatti 2017-2019). Already mentioned as 'Lunaria quarta' by Andrea Cesalpino in his De Plantis libri XVI (Cesalpino 1583: 369), it was described as Alyssum bertolonii by Nicaise A. Desvaux (1814), who received in 1810 a collection by Antonio Bertoloni from the ultramafic outcrops near Sarzana in eastern Liguria. Around the middle of the last century Minguzzi and Vergnano (1948) published a small paper to present a big scientific discovery: the ashes of $O$. bertolonii plants from the serpentine area of Monte Ferrato close to Prato contained over $1 \%$ of $\mathrm{Ni}$. That unexpected finding demonstrated for the first time

that a seed plant could take up $\mathrm{Ni}$ from the soil and accumulate it in its shoot tissues in concentrations hundreds of times greater than those reported before for any flowering plant. Since then, $O$. bertolonii has been widely used for the investigation of the mechanisms of homeostatic tolerance and accumulation of metals, acquiring a prominent position as a Ni-hyperaccumulating model species (see Galardi et al. 2007 and references therein). Moreover, this plant was also considered as a potential agent for biotechnological applications such as phytoremediation and phytomining (Robinson et al. 1997; see also Kidd et al. 2018). Many years after the first discovery, other studies on Odontarrhena C.A. Mey. from different Mediterranean and European regions (Brooks and Radford 1978; Morrison et al. 1980; Reeves et al. 1983) led to the realization that Ni-accumulation ability is a genus-wide trait among the taxa found on serpentine soils. At present, there is evidence that all populations and species of this genus from ultramafic soils can accumulate nickel in concentrations above the established hyperaccumulation threshold of $1000 \mathrm{\mu g} \mathrm{g}^{-1}$ of dry-weight in their leaves, with the only known exception of O. sibirica (Willd.) Španiel, Al-Shehbaz, D.A. German \& Marhold (Bettarini et al. 2020). Remarkably, this physiological ability is apparently absent in species of Alyssum L., supporting Odontarrhena as a separate genus in line with clear morphological and molecular phylogenetic evidence (Cecchi et al. 2010; Rešetnik et al. 2013).

As other congeneric species, $O$. bertolonii shows inter- and intra-population variability in morphology and $\mathrm{Ni}$-accumulation ability (Galardi et al. 2007), as well as considerable genetic differentiation and isolation by distance between the numerous populations scattered over the Tuscan ultramafic outcrops (Mengoni et al. 2003). Concerning morphology, the monographer Nyárády (1928) observed variation in fruit shape and trichome density on silicle valves, and described two subspecies: subsp. bertolonii, endemic to Italy, and subsp.

CONTACT Federico Selvi federico.selvi@unifi.it 0 Department of Agriculture, Food, Environment and Forestry, Laboratories of Botany, Università di Firenze, P.le Cascine 28, 50144 Firenze, Italy

(c) 2021 Societá Botanica Italiana 
scutarinum Nyár., from north Albania. Based on phylogenetic evidence and a recent taxonomic revision, however, subsp. scutarinum is to be excluded from the circumscription of $O$. bertolonii and included in that of the Balkan species O. chalcidica (Janka) Španiel, Al-Shehbaz, D.A. German \& Marhold (Cecchi et al. 2018). In 'Alyssum' bertolonii 'f. typicum' Nyárády (1928) also recognized two subforms, 'glabrum Nyár.' and 'stellatocarpum Nyár.', for plants with glabrous or sparsely pubescent silicle valves, respectively. In addition, he also described a form named 'ramosum Nyár.' for the plants with more richly branched inflorescences. However, none of these forms or subforms have been recognized in the Italian and European taxonomic literature because they are based on individual variations in characters of poor taxonomic value.

In a paper on the systematics and biogeography of the central western Mediterranean taxa, Cecchi et al. (2013) also reported intraspecific variation in chromosome number, a previously unknown aspect of the biology of 0 . bertolonii. Plants from the easternmost and more continental parts of the species range in Tuscany were tetraploid, rather than diploid as reported by previous authors for more western plants of the species (Arrigoni and Mori 1976; Arrigoni et al. 1980). From that study, however, it was not possible to assess the distribution of diploid vs. tetraploid plants/populations and it was unclear whether tetraploid plants were mixed with diploid ones within one or more populations. Based on wider field collections of plant material across the whole species range, we could shed light on this issue and unravel the existence of cytotypes and their distribution. This also allowed to test the hypothesis that polyploidy can enhance seed germination and plant phenotype, providing adaptive and reproductive advantage in stressful environments (Bretagnolle et al. 1995; Sattler et al. 2016; Godfree et al. 2017; Stevens et al. 2020).

\section{Materials and methods}

\section{Plant material}

Herbarium specimens in $\mathrm{FI}$ and FIAF were investigated for general morphology and geographic distribution of the species. Examined specimens included material revised and annotated by the monographer E. Nyárády in the year 1932, and referred by him to the forms and subforms mentioned above (Introduction). Herbarium material, however, was not suitable for karyological and morphometric studies. In summer 2020, a field sampling campaign was therefore conducted to collect plant material for these analyses. Six populations were sampled trying to cover the geographic range of the species in Tuscany and Liguria and including the type locality on the serpentine outcrops close to the village of Falcinello in the province of La Spezia (Table 1, Figure 1).

Populations were sampled between mid-June and mid-July, collecting hundreds of mature fruits (silicles) from at least ten individuals growing at least $3 \mathrm{~m}$ apart from each other. For morphometric observations, representative plant portions were collected from eight randomly chosen adult plants growing in the sparse vegetation of the Armerio denticulatae-Alyssetum bertolonii Arrigoni association. Plants growing under the canopy of trees, especially pines, were excluded as shade and soil conditions may influence the species phenotype and growth (Selvi et al. 2017). We avoided to collect whole plants (even of large size), not to cause severe damage to the populations included in some cases in protected areas. Representative plant parts were cut with scissors from the base and included sterile shoots with leaves and a variable number of fertile stems with fruits. At least one herbarium voucher per population is deposited in FIAF.

\section{Seed germination and karyology}

After field collection in summer 2020, seeds were stored at room temperature until mid-September and then kept at $4{ }^{\circ} \mathrm{C}$

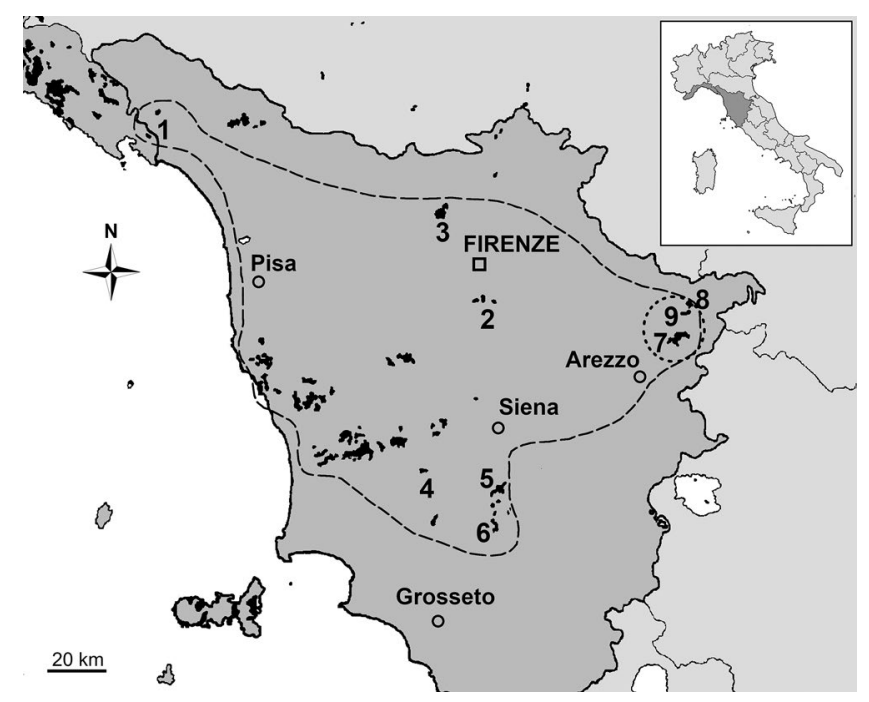

Figure 1. Distribution range of Odontarrhena bertolonii in Tuscany and Liguria; the species occurs on all the ultramafic outcrops (black spots) that are enclosed within the area delimited by the dashed line; numbers indicate the population sampling sites, as in Table 1; population no. 1 is that from the type locality; tetraploid populations $(7,8,9)$ are delimited by a dotted circle.

Table 1. List of Odontarrhena bertolonii populations investigated, with geographical details and month/year of seed/plant collection.

\begin{tabular}{|c|c|c|c|c|c|}
\hline & Population sampled & (Code) & Lat $\mathrm{N}$, Long $\mathrm{E}$ & Altitude $(\mathrm{m})$ & Seed collection \\
\hline 1 & Liguria, Falcinello & $\mathrm{Fa}$ & $44^{\circ} 08 \bigotimes 36 \bigotimes, 9^{\circ} 57 \rrbracket 10 \bigotimes$ & $90-120$ & Jul 20 \\
\hline 2 & Tuscany, Impruneta, Sassi Neri & $\operatorname{Im}$ & $43^{\circ} 40 \bigotimes 37 \rrbracket, 11^{\circ} 16 \rrbracket 07 \rrbracket$ & $270-280$ & Jul 2018, 2020 \\
\hline 3 & Tuscany, Galceti, Mt. Ferrato & $\mathrm{Ga}$ & $43^{\circ} 54 \rrbracket 43 \bigotimes, 11^{\circ} 05 \otimes 05 \bigotimes$ & $120-140$ & Jul 2020 \\
\hline 4 & Tuscany, towards Travale ${ }^{a}$ & $\operatorname{Tr}$ & $43^{\circ} 11 \otimes 20 \bigotimes, 11^{\circ} 02 \rrbracket 11 \rrbracket$ & $475-480$ & Aug 2019 \\
\hline 5 & Tuscany, Casciano di Murlo & $\mathrm{Mu}$ & $43^{\circ} 08 \rrbracket 25 \bigotimes, 11^{\circ} 20 \bigotimes 37 \rrbracket$ & $460-470$ & Jun 2020 (seeds not ripe) \\
\hline 6 & Tuscany, Casal di Pari, Casenovole ${ }^{a}$ & $\mathrm{Ca}$ & $43^{\circ} 02 \otimes 01 \rrbracket, 11^{\circ} 19 \bigotimes 48 \rrbracket$ & $320-325$ & Jul 2018 \\
\hline 7 & Tuscany, Anghiari, Mt. Rognosi & An & $43^{\circ} 34 \rrbracket 32 \rrbracket, 12^{\circ} 00 \rrbracket 57 \rrbracket$ & $440-470$ & Aug 2018, Jun 2020 \\
\hline 8 & Tuscany, Pieve S. Stefano, Mt. Petroso & $\mathrm{Pi}$ & $43^{\circ} 38 \otimes 57 \bigotimes, 12^{\circ} 03 \rrbracket 22 \rrbracket$ & $450-480$ & Jun 2020 \\
\hline 9 & Tuscany, Pieve S. Stefano, Formole & $\mathrm{PiF}$ & $43^{\circ} 38 \nabla 38 \otimes, 12^{\circ} 03 \rrbracket 06 \bigotimes$ & $420-430$ & Aug 2018 \\
\hline
\end{tabular}

${ }^{a}$ Accessions not investigated for morphology. 
until 15 January 2021. Before analyses, two samples of 20 randomly selected seeds of each investigated accessions were weighted with a Mettler Toledo precision balance to estimate intraspecific variation in dry seed mass. Seeds were then used to obtain plant material for karyological investigations and to compare germination between the populations $\mathrm{Fa}$, $\mathrm{Ga}, \mathrm{Im}, \mathrm{Pi}$ and $\mathrm{An}$; seeds of the population $\mathrm{Mu}$ were still not ripe and could not be germinated. We could also analyse germination of older seeds collected in summer 2018 of the populations PiF, An, Im and Ca (Table 1) and conserved at $4^{\circ} \mathrm{C}$ for ca. 30 months. In January, we placed 100 seeds in four Petri dishes (25 each) for each accession, on wet filter paper (distilled water) at room temperature $\left(\mathrm{ca} .18^{\circ} \mathrm{C}\right.$ ) close to a natural light source; no other treatments were used (Chaussat and Le Deunff 1975). The number of germinated seeds was counted every day between 8.30 and $10.30 \mathrm{am}$, until no new germination occurred for five consecutive days. Germination percentages of the populations were compared using Analysis of Variance (ANOVA) followed by post-hoc Tukey test, after checking data normality with the Lilliefors test.

Ten germinated seeds of the populations $\mathrm{Fa}, \mathrm{Im}, \mathrm{Ga}, \mathrm{Tr}$, $\mathrm{Ca}, \mathrm{An}, \mathrm{Pi}$ and PiF were used for karyological analyses. These were pre-treated with $0.002 \mathrm{M}$ 8-hydroxyquinoline for $3.5 \mathrm{~h}$ at room temperature and then fixed overnight in ethanol/ glacial acetic acid (3:1). When necessary, they were preserved in $70 \%$ ethanol at $3-4^{\circ} \mathrm{C}$ until preparation. Seedlings were then rinsed in distilled water, hydrolysed in $1 \mathrm{M} \mathrm{HCl}$ at $60^{\circ} \mathrm{C}$ for 6-7 min and stained in lacto-propionic orcein overnight. The meristematic tissue of the root tips was then dissected and squashed on glass slides in a drop of $45 \%$ acetic acid. Metaphase plates were examined with a Zeiss Axioscop light microscope under oil immersion $(\times 100)$, and photographed with a Nikon digital system.

\section{Phenotype analysis}

To analyse the main patterns of phenotypic variation, limited to macro-morphology, we used a morphometric approach based on quantitative continuous characters. The eight fruiting specimens from each population were scored for 13 major quantitative characters concerning the height of the plant, the size of the basal and cauline leaves (three per specimen, when present), the mean length of the inflorescence and the mean number of lateral branches, the size of the fruit and of the seed (mean of five units per specimen). Measurements of silicle and seed size, including wing, were taken at a Nikon stereomicroscope and a Dino-Lite \& Dino-Eye digital microscope connected to a DinoCapture 2.0 software
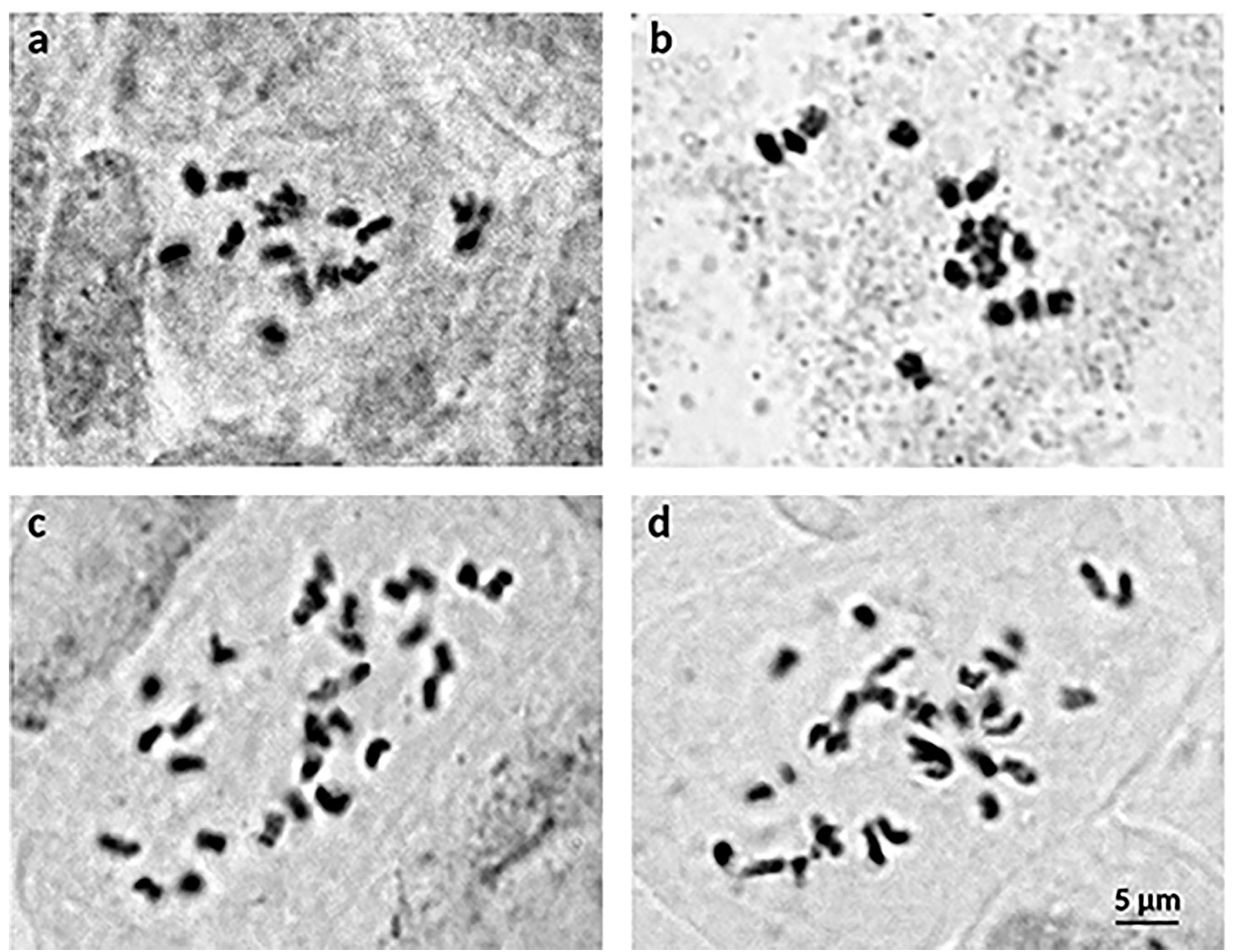

Figure 2. Micrographs of metaphase chromosome plates of Odontarrhena bertolonii from: (a) Sarzana, Falcinello (Fa); (b) Prato, Galceti (Ga); (c) Pieve Santo Stefano, Mt. Petroso (Pi); (d) Anghiari, Monti Rognosi (An). 
vs. 1.5.38B. These selected characters are of taxonomic relevance in Odontarrhena and were already used in morphometric analyses of Mediterranean species of the genus (Cecchi et al. 2013, 2020).

To summarize and display variation in the data set, the resulting matrix was standardized (subtracting mean and dividing by standard deviation) and subjected to principal component analysis (PCA) with PAST version 3.26 (Hammer et al. 2001). Next, univariate inter-population comparisons for more significant characters were performed using the non-parametric Kruskal-Wallis test followed by Mann-Whitney pairwise comparisons with Bonferroni correction. Diploid and tetraploid accessions were finally compared with the MannWhitney $U$ test.

\section{Results}

\section{Karyology}

In the five populations of $\mathrm{Fa}, \mathrm{Im}, \mathrm{Ga}, \mathrm{Tr}$ and $\mathrm{Ca}$ the chromosome number of all examined plants was $2 n=2 x=16$ (Figure $2(a, b))$. These populations are, therefore, diploid. Chromosomes were small sized, ranging between 2 and $2.5 \mu \mathrm{m}$, and mostly metacentric to submetacentric; no satellite chromosome pairs were observed. Karyotype formulas and asymmetry indexes could not be determined with precision and are not shown here. Conversely the examined individuals of the three populations from the upper Tiber valley, Pi, PiF and An, showed the number $2 n=4 \times=32$ and were thus tetraploid (Figure $2(c, d))$. The karyotype consisted of small metacentric and submetacentric chromosomes, apparently very similar to those of the diploids. However, a homologue pair was provided with satellites.

\section{Seed germination}

The tested populations showed significant differences in seed germination responses, in terms of time and proportion of germinated seeds (Figure $3(a, b)$ ). Only two days after the start of the test, the proportion of germinated seeds from $\mathrm{Pi}$ and An 2020 ranged between 5\% and 16\%; the peak was

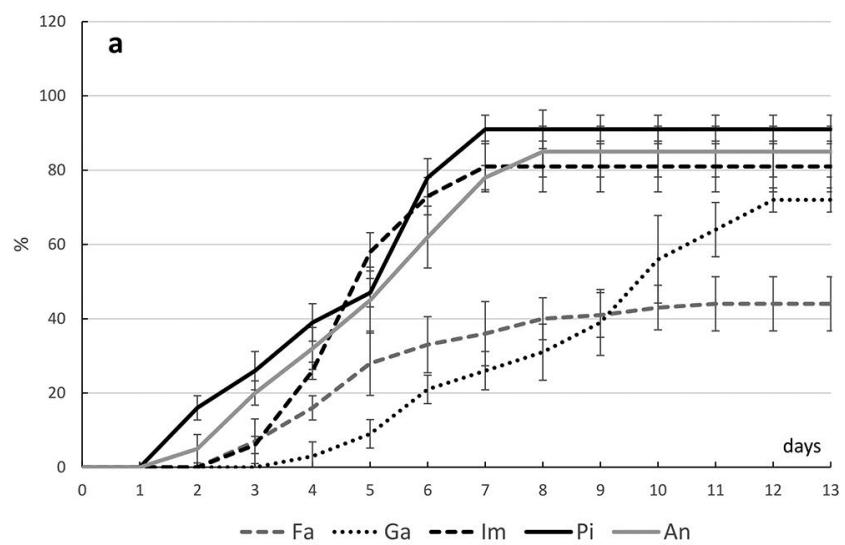

reached after $7-8$ days, with percentages of $91 \% \pm 3.83 \%$ and $85 \% \pm 6.81 \%$, respectively (mean of the four Petri dishes). The seeds from Im, Fa and Ga 2020 had a slower germination. This started after 3 or 4 days, and reached the peak after 7 $(\mathrm{Im})$ and 11 days, with mean percentages of $81 \% \pm 3.73 \%$, $44 \% \pm 7.3 \%$ and $72 \% \pm 3.2 \%$, respectively. Overall, there was a highly significant difference between the examined populations $(F=39.57, p<0.001)$; Tukey test showed that $\mathrm{Pi}$ and An had significantly higher percentages of seed germination than $\mathrm{Ga}$ and $\mathrm{Fa}(p<0.05)$ not as compared with $\operatorname{Im}(p>0.05)$. Hence, the diploid seeds showed a higher variability than the tetraploid ones. Comparing overall germination percentages of diploid and tetraploid accessions resulted in a significant difference (Mann-Whitney $U=6.5 ; p=0.0015$ ).

In all cases, seeds produced in 2018 showed a lower germination rate than those produced in 2020. Reduction was ca. $45 \%$ and $42 \%$ for $\mathrm{Pi}$ and $\mathrm{An}$, and $52 \%$ for $\mathrm{Im}$; this parameter could not be determined for Fa and Ga as 2018 seeds of these accessions were not available. Mean germination percentage of Ca 2018 was only $16 \% \pm 3.3$. Differences between populations were marked (Figure 3(b)). Germination started after two days in the accessions $\mathrm{Pi}$ and $\mathrm{An}$, and reached the maximum after 10 days with percentages of ca. $45 \% \pm 6.8 \%$. Seeds from Ca and Im started to germinate after three days, reaching their maximum after 8 days, with proportions of $16 \%$ and $29 \%$, respectively. Differences between the examined populations were highly significant $(F=72.12, p<0.001)$; Tukey's test showed higher germination percentages in $\mathrm{Pi}$ and $\mathrm{An}$, as well as in Im compared to Ca $(p<0.001)$.

\section{Phenotype analysis}

The PCA of the standardized data matrix explained $61 \%$ of the total variation (PC1: 49.5\%; PC2: 11.4\%). The resulting scatterplot (Figure 4) showed continuous variation between the 48 samples, but those of populations $\mathrm{Pi}$ and An were all grouped on the positive part of $\mathrm{PC1}$, while those from the other populations were mainly lying on the negative part; the overlapping area between these two groups of populations was relatively small. The most important variables in producing this pattern were style length, width of the seed and of its wing, plant height and size of the basal leaves; all

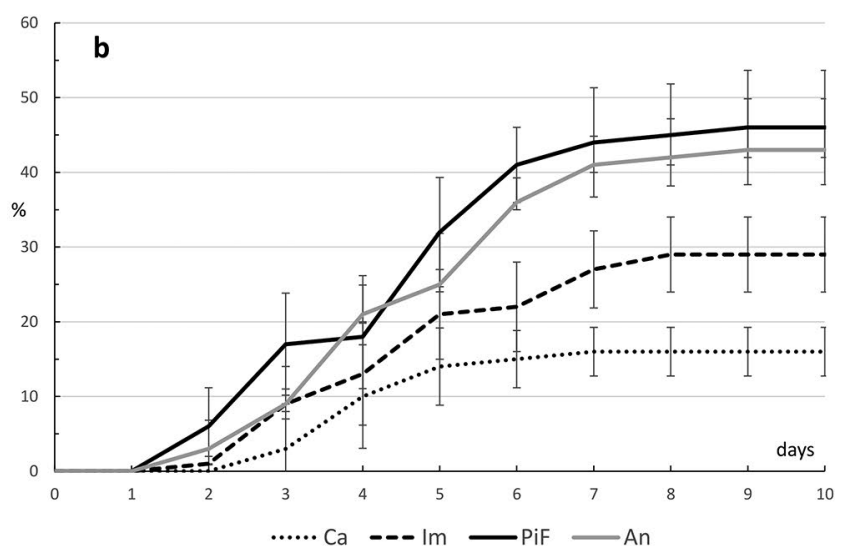

Figure 3. Seed germination curves in diploid and tetraploid accessions of Odontarrhena bertolonii; (a) seeds collected in 2020; (b) seeds collected in 2018; population codes as in Table 1. 


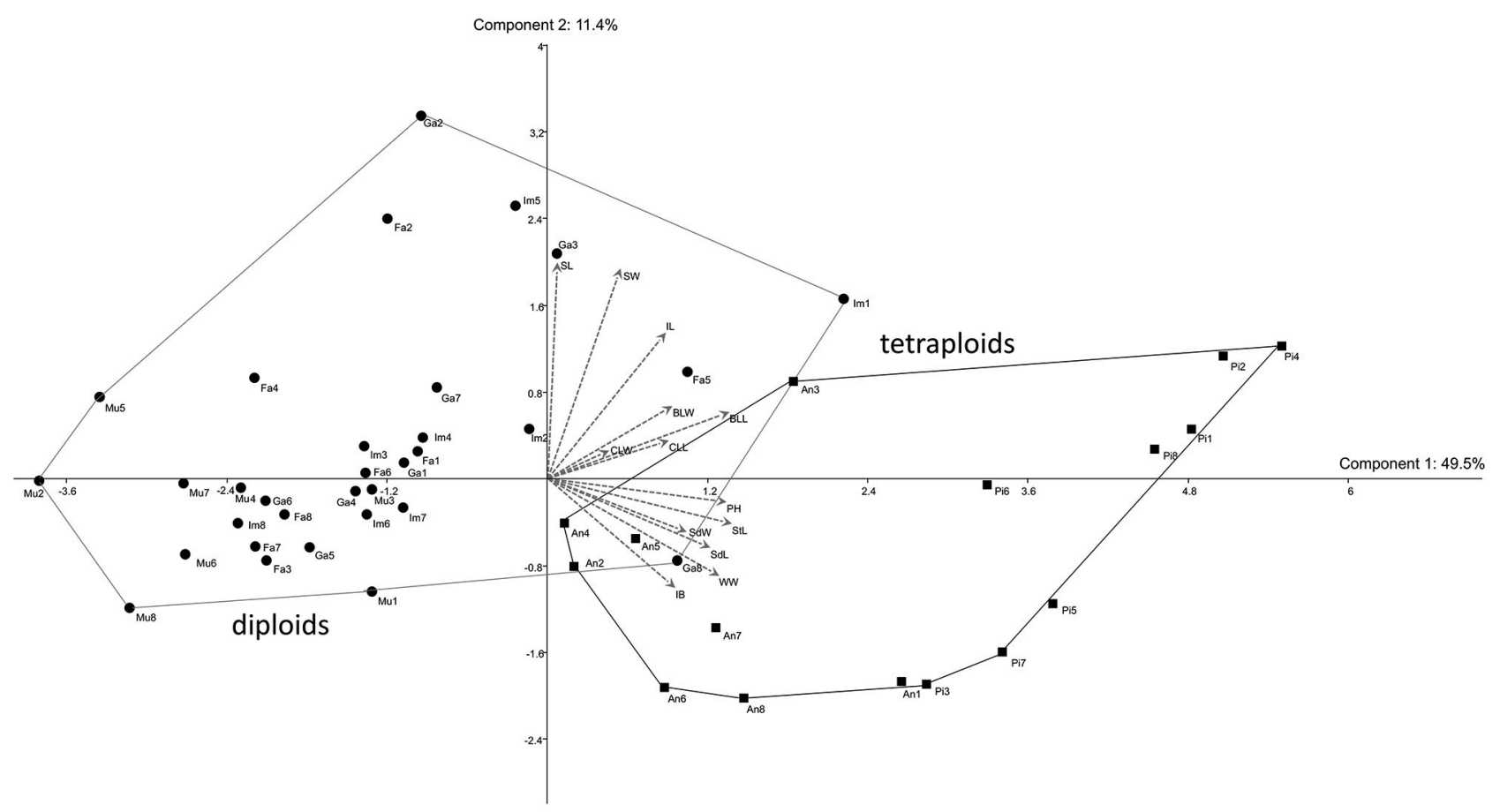

Figure 4. PCA scattergram showing phenotypic relationships between plants of six populations of Odontarrhena bertolonii from Liguria and Tuscany, based on 13 quantitative characters (vectors). Population and character codes are as in Tables 1 and 2, respectively. Black dots and black squares represent diploid and tetraploid plants, respectively.

Table 2. Mean values \pm standard deviation of 13 characters measured for six populations of Odontarrhena bertolonii.

\begin{tabular}{|c|c|c|c|c|c|c|c|}
\hline Character & Code & $\mathrm{Fa}$ & Im & $\mathrm{Ga}$ & $\mathrm{Mu}$ & An & $\mathrm{Pi}$ \\
\hline Plant height (cm) & $\mathrm{PH}$ & $27.4 \pm 5.1$ & $25.5 \pm 4.7$ & $30.7 \pm 7.4$ & $21.6 \pm 2.7^{*}$ & $39.5 \pm 6.7^{*}$ & $49.6 \pm 5.5^{*}$ \\
\hline Basal leaf length (mm) & BLL & $9.8 \pm 1.6$ & $11.4 \pm 1.5$ & $10.4 \pm 1.1$ & $7.5 \pm 1.8^{*}$ & $11.7 \pm 1.3$ & $14.6 \pm 2.6^{*}$ \\
\hline Basal leaf width (mm) & BLW & $2.4 \pm 0.5$ & $3.1 \pm 0.7$ & $2.7 \pm 0.5$ & $2.9 \pm 0.2$ & $2.8 \pm 0.2$ & $3.5 \pm 0.5^{*}$ \\
\hline Cauline leaf length $(\mathrm{mm})^{*}$ & CLL & 6.5 & $10.1 \pm 2.1$ & 8.0 & $7.2 \pm 2.1$ & $11.3 \pm 1.6^{*}$ & $12.9 \pm 3.1^{*}$ \\
\hline Cauline leaf width $(\mathrm{mm})^{*}$ & CLW & 1.6 & $2.5 \pm 0.4$ & 1.5 & $2.1 \pm 0.5$ & $1.6 \pm 0.2$ & $3.1 \pm 0.6$ \\
\hline Mean inflorescence length $(\mathrm{cm})$ & IL & $5.7 \pm 1.0$ & $5.5 \pm 0.7$ & $6.5 \pm 1.0$ & $4.4 \pm 0.4^{*}$ & $5.4 \pm 0.5$ & $7.0 \pm 1.1$ \\
\hline Mean no. of inflor. branches & IB & $3.9 \pm 1.4$ & $3.8 \pm 0.6$ & $3.2 \pm 1.3^{*}$ & $3.3 \pm 0.7^{*}$ & $5.3 \pm 0.8^{*}$ & $5.4 \pm 0.7^{*}$ \\
\hline Silicle length (mm) & SL & $4.4 \pm 0.3$ & $4.1 \pm 0.2$ & $4.2 \pm 0.3$ & $4.3 \pm 0.3$ & $4.2 \pm 0.2$ & $4.3 \pm 0.2$ \\
\hline Silicle width (mm) & SW & $2.3 \pm 0.2$ & $2.6 \pm 0.4$ & $2.4 \pm 0.4$ & $2.2 \pm 0.1$ & $2.4 \pm 0.3$ & $2.5 \pm 0.2$ \\
\hline Style length (mm) & StL & $1.1 \pm 0.1$ & $1.1 \pm 0.1$ & $1.1 \pm 0.1$ & $1.0 \pm 0.1$ & $1.3 \pm 0.1^{*}$ & $1.7 \pm 0.1^{*}$ \\
\hline Seed length (mm) & SdL & $2.0 \pm 0.1$ & $2.0 \pm 0.1$ & $2.1 \pm 0.0$ & $2.0 \pm 0.1$ & $2.1 \pm 0.1$ & $2.2 \pm 0.1$ \\
\hline Seed width (mm) & SdW & $1.1 \pm 0.1$ & $1.1 \pm 0.1$ & $1.1 \pm 0.1$ & $1.1 \pm 0.1$ & $1.2 \pm 0.1^{*}$ & $1.3 \pm 0.1^{*}$ \\
\hline Seed wing width (mm) & WW & $0.1 \pm 0.0$ & $0.1 \pm 0.0$ & $0.1 \pm 0.0$ & $0.1 \pm 0.0$ & $0.2 \pm 0.0^{*}$ & $0.2 \pm 0.0^{*}$ \\
\hline
\end{tabular}

Standard deviation values for character CLW are missing when only one sample per population was measured, the other samples lacking cauline leaves.

*Significant differences at $p<0.05$.

these measurements were significantly higher in the An and, even more, in the Pi samples (Table 2). Overall differences between the pooled diploid and tetraploid populations in these characters were always significant at $p<0.001$ (Figure $6(a-d))$. Also, seed mass in the tetraploids was on average $28.3 \%$ higher than in diploids (mean weight of 20 seeds = $0.0118 \pm 0.0004$ vs. $0.0092 \pm 0.0003 g ; p<0.01$ ). Cauline leaves were often absent in fruiting specimens of the diploid populations, while still present in most of the tetraploid plants from $\mathrm{Pi}$ and $\mathrm{An}$. An additional difference was found in the mean number of lateral branches per inflorescence, which was $5.3 \pm 0.7$ for $\mathrm{Pi}$ and An vs. $3.5 \pm 1.2$ in the other populations (Table 2; Figure 7). Fruit morphology was relatively uniform between populations, with no consistent differences between diploids and tetraploids in the size and shape of the silicles (Figure 5(a)). Presence of disciform stellate trichomes on silicle valves was an inconstant character between and within most populations. However, trichomes were present in several samples of populations $\mathrm{Fa}, \mathrm{Mu}, \mathrm{Im}, \mathrm{Tr}, \mathrm{Ca}$ and Ga (ca. $60 \%$ of the individual samples with at least part of silicles showing such trichomes before complete maturation), while these were apparently absent on the fruits of plants from populations $\mathrm{Pi}$ and An.

Finally, the An and Pi plants were more robust and had a thicker woody stem, at base measuring $3.5-6 \mathrm{~mm}$ in diameter vs. $2-3.5 \mathrm{~mm}$ in the other accessions.

\section{Discussion}

Our karyological findings support that the chromosome number of plants of $O$. bertolonii from the easternmost part of the species range in the Upper Tiber valley is $2 n=32$, confirming the previous observation by Cecchi et al. (2013). No intra-population variation was observed, providing 
a
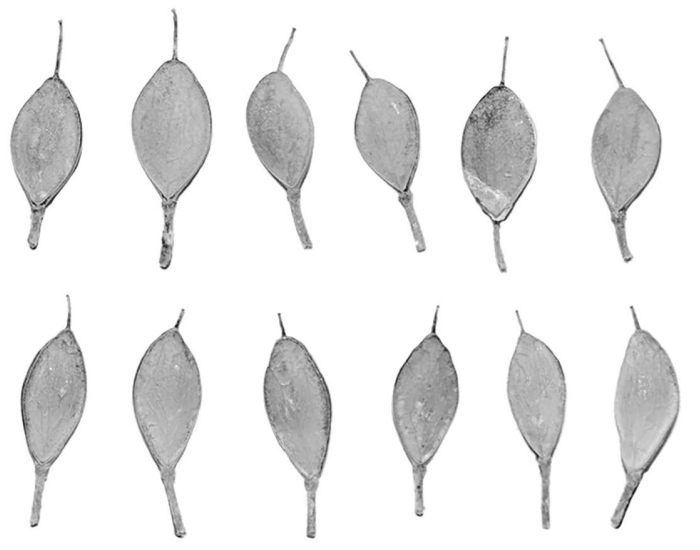

b
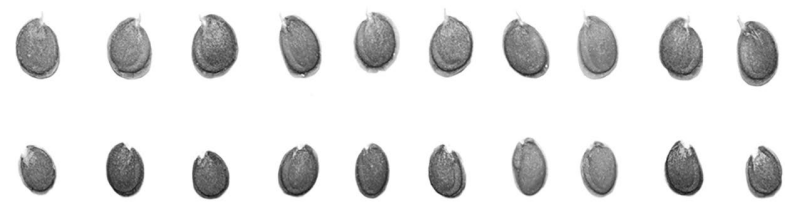

$5 \mathrm{~mm}$

Figure 5. Silicles (a) and seeds (b) of the accessions Pi (tetraploid, above) and Fa (diploid, below).
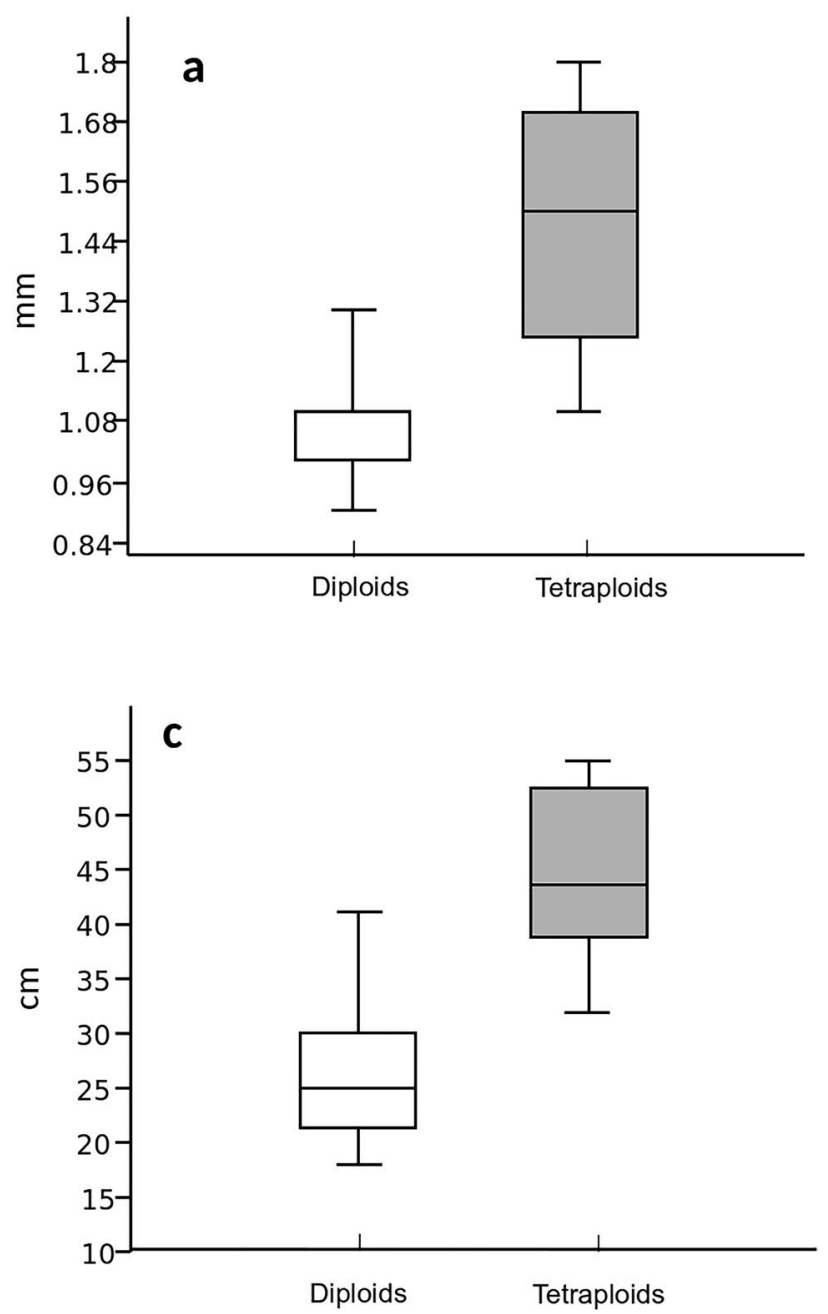

evidence that these peripheral populations are uniformly tetraploid. The other samples from the more western and southern parts of the species range resulted diploid with $2 n=16$, thus pointing to the allopatric distribution of the two cytotypes. At present, however, it cannot be excluded that tetraploid accessions occur within the range of the diploids or vice-versa. Mechanisms of genome doubling via union of unreduced conspecific gametes (autotetraploidy) seem plausible to explain the origin of the tetraploid complement in the eastern populations, but more studies would help to support this hypothesis and exclude an allo-tetraploid origin. Tetraploidy based on $x=8$ has a significant frequency in tribe Alysseae and genus Odontarrhena (Španiel et al. 2015), and is typical of at least two Italian endemics, $O$. tavolarae (Briq.) Cecchi \& Selvi from Sardinia and O. argentea (All.) Ledeb. from the ultramafics in the western Alps and the northern Apennines (Cecchi et al. 2013; Bartolucci et al. 2018; Pignatti 2017-2019). Molecular phylogenetic data supported the close relationship between the Apennine and alpine populations of $O$. argentea and their position in a clade separate from that of $O$. bertolonii, which includes both the diploid and tetraploid accessions investigated here. Hence, the karyological convergence between tetraploid $O$. bertolonii and $O$. argentea does not seem to reflect direct relationship and has likely originated through distinct events, though possibly similar mechanisms. On the other hand,
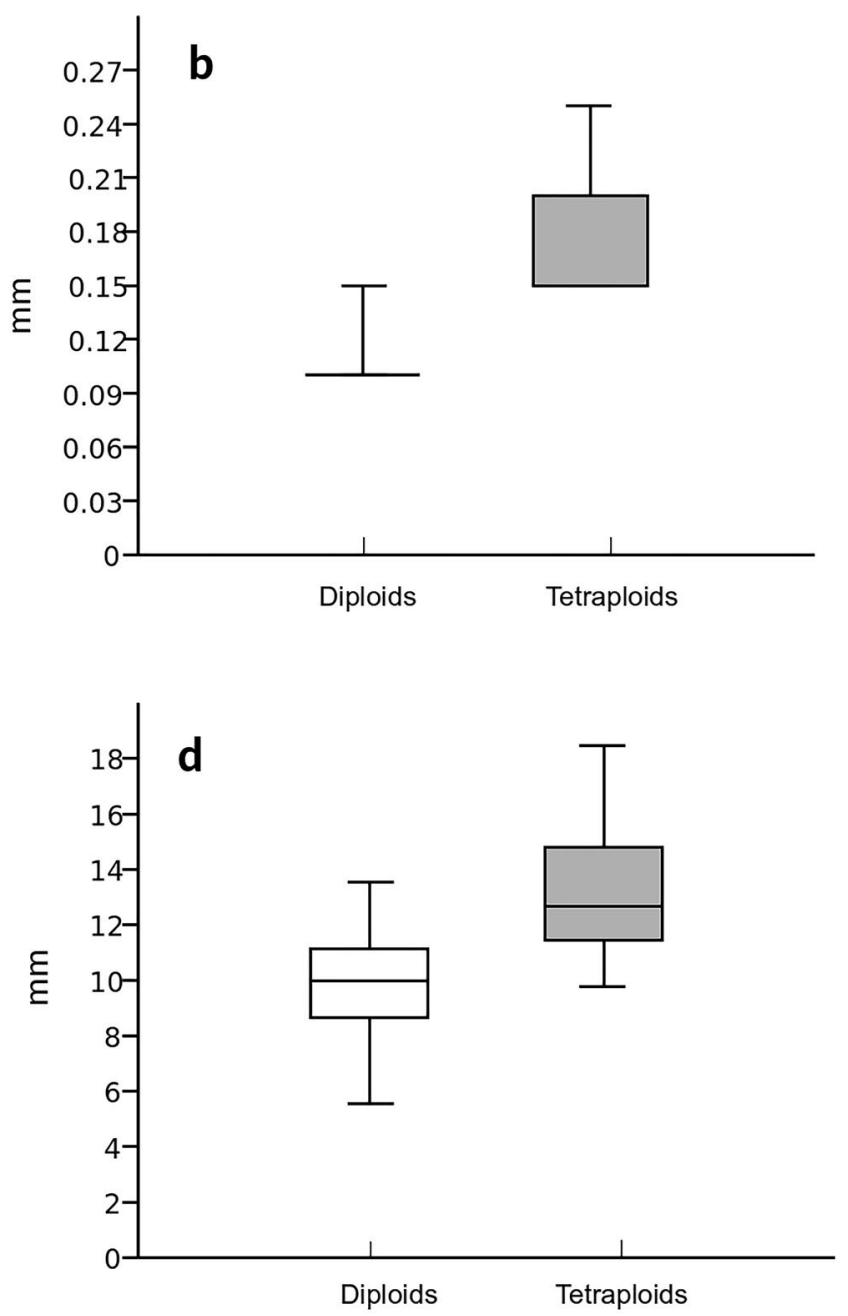

Figure 6. Box-Whisker plots showing diploid vs. tetraploid variation in (a) style length (StL); (b) width of the seed wing (WW); (c) plant height (PH); (d) length of the basal leaves (BLL). 


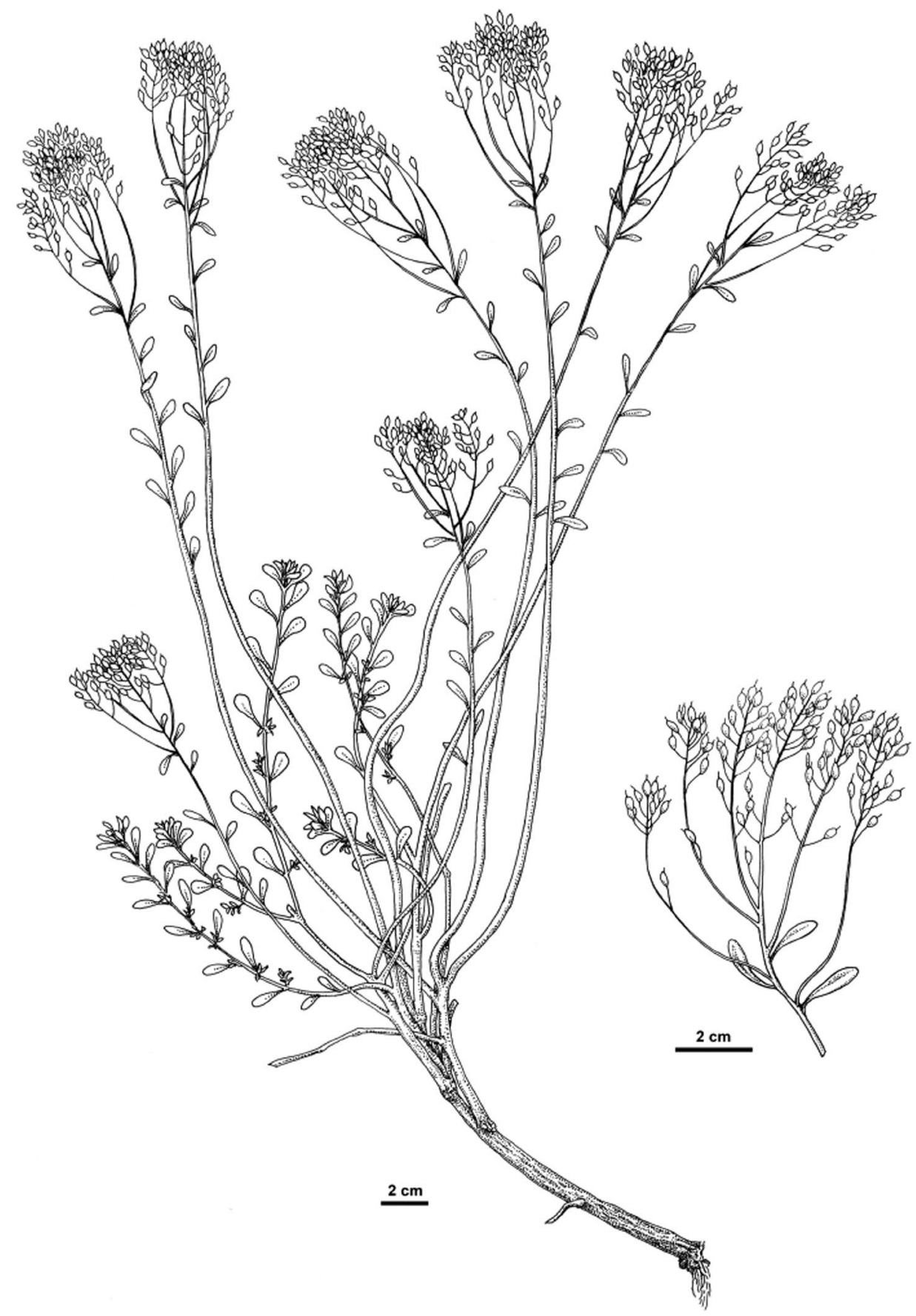

Figure 7. Odontarrhena bertolonii subsp. cesalpina from Pieve Santo Stefano, Mt. Petroso (based on the holotype, Fl) showing habit (left) and a fruiting branch (right). Original drawing by L. Vivona.

past events of gene exchange and homoploid hybridization between tetraploid $O$. bertolonii and Apennine $O$. argentea cannot be excluded, as found in other tetraploid species complexes of the genus involved in extensive genetic admixing (Coppi et al. 2020). However, the present-day geographic separation between these two groups of populations on outcrops that lie over $190 \mathrm{~km}$ from each other makes such hybridization events unlikely, also considering the inability of both species to grow outside serpentine soils and therefore the unlikelihood of their being in close proximity, even in the past.
Unexpected differences were found in the seed germination behaviour of the accessions investigated, a previously unknown aspect of the biology of $O$. bertolonii. Variation in seed viability occurred between the diploid accessions, with a different of germination percentage as large as 37\% between the accessions from the type locality of Falcinello and that from Impruneta near Firenze. Clear differences were also associated with the ploidy level of the populations, since tetraploids from the Upper Tiber valley showed on average faster rates and higher percentages of seed germination than diploids, in line with their increased seed size and mass. Our findings support evidence from previous 
studies that polyploidy may influence within-species variation in seed germination and seedling establishment. Working on Dactylis glomerata L., Bretagnolle et al. (1995) found that seeds from tetraploid plants germinated faster and to a higher percentage than those from diploid plants, regardless of their initial mass. Similarly, Stevens et al. (2020) observed that the tetraploid plants of the grass Themeda triandra Forssk., produced heavier and more viable seeds than diploids, associated with a more pronounced dormancy. These authors suggested that seed and seedling traits of tetraploids are generally better adapted to stressful environments than diploids and have an increased fitness under extreme conditions of drought and heat (see also Madlung 2013). According to Godfree et al. (2017) polyploid advantage in stressful environments is caused by two distinct processes, homeostatic maintenance of reproductive output under elevated abiotic stress, and fixed differences in seed development. In the case of 0 . bertolonii, however, polyploidy and increased seed fitness cannot be directly related to different levels of environmental stress, since the species habitat conditions in the ultramafic sites in the upper Tiber valley and in the more western parts of the species regions are apparently similar and equally stressful, suggesting constitutive biological differences between the respective inhabiting populations. Moreover, our findings from the comparison between the seeds produced in summer 2018 and 2020 suggested that polyploids maintain seed viability through time better than diploids, likely due to a more pronounced dormancy of the embryo (Stevens et al. 2020).

Phenotypic traits analysed in this study pointed to a higher vigour in the tetraploid plants, which generally showed a larger size and a more robust habit, with thick, much branched woody stems. This was supported by the examination of the herbarium collections from the upper Tiber valley, especially those by Pichi Sermolli (1948), and nicely matches the early description by Cesalpino's (1583: 369), who wrote 'Lunaria quarta fruticosior,...cespites sunt lati; cauliculis duris, dodrantalibus.... Tetraploid plant samples were on average over $20 \%$ taller, in line with findings by Corneillie et al. (2019) who detected the same difference in the stem height of diploid-tetraploid plants of Arabidopsis thaliana (L.) Heynh. Moreover, tetraploid accessions of $O$. bertolonii produced thicker stems with a more strongly lignified base, and were more frequently provided with cauline leaves at the fruiting stage, whereas cauline leaves were lacking in most fruiting specimens of the diploid plants because of their earlier abscission. An additional difference consisted in the usually more richly branched inflorescences of tetraploids, which implies a higher production of flowers, and therefore of fruits and seeds. Polyploids are thus likely to have a higher reproductive output, as found in other species with diploid and tetraploid cytotypes (Godfree et al. 2017). Seed traits were in line with this general trend of variation, as tetraploids produced, on average, both larger and heavier seeds. Higher amounts of secondary endosperm is a likely reason for their increased mass, which is in turn related to faster germination, and probably, early growth of seedlings (Bretagnolle et al. 1995). Also, seeds of tetraploids are usually provided with a more developed wing than diploids, as already found in the central western Mediterranean species (Cecchi et al. 2013). Though difficult to explain in functional terms, this trait could possibly influence positively the dispersal ability of the seeds by counterbalancing the negative effect of their increased mass. Concerning fruits, no significant quantitative differences were found among populations and between diploids and tetraploids. However, silicles of the latter group were generally glabrous, while trichomes were often present in the more western plants, including those from the type locality in Liguria. These trichomes are provided with calcium carbonate biomineralizations (Hopewell et al. 2021).

Further cytogenetic and molecular studies will help to establish the origin of the tetraploid populations and the patterns of diversity and differentiation within this remarkable endemic species.

\section{Taxonomic implications}

The peripheral populations in the upper Tiber valley lie in large geographical isolation as compared with those in central, southern and western Tuscany and eastern Liguria, because of the distance between the respective ultramafic outcrops and the presence of mountain chains such as Pratomagno and part of the northern Apennines. Besides this physical barrier, the tetraploid chromosome complement is likely to determine a greater genetic isolation as compared with diploids. Also in view of their weak, but still recognizable, morphological divergence, the eastern populations appear as distinct biological units for which we propose taxonomic recognition at the subspecies rank, as in the treatment below.

Odontarrhena bertolonii (Desv.) Jord. \& Fourr., Brev. PI. Nov. 2: 6. (1868) subsp. bertolonii $\otimes$ Alyssum bertolonii Desv., J. Bot. Agric. 3: 172, 185. 1815 ['1814'], basionym $\otimes$ Alyssum bertolonii Desv. f. typicum Nyár. in Bul. Grăd. Bot. Cluj 7: 100. 1928, nom. superfl. $\otimes$ Alyssum bertolonii Desv. f. typicum Nyár. subf. glabrum Nyár. in Bul. Grăd. Bot. Cluj 7: 100. 1928, nom. superfl. \Alyssum bertolonii Desv. f. typicum Nyár. subf. stellatocarpum Nyár. in Bul. Grăd. Bot. Cluj 7: 100. 1928, nom. superfl.

Locus classicus: 'Habitat in Liguria'. Lectotype (here designated): 'Alyssum argenteum W./Sarzana [in Bertoloni's handwriting]/mis. Bertoloni 1810', G00204531 G-DC (photo)!

Note. In P there is a second specimen (P05373358, photo!) collected and annotated by Bertoloni as follows: 'Alyssum argenteum W. Bert./Amoen. Ital./Nariat seminibus marginatis, et margine destitutis. Hinc Alyssum Bertolonii Desv. est species nullius momenti/Legi prope Sarzanam in monte dicto Nuda di Ponzano/A. Bertoloni'. Though this specimen was probably sent by Bertoloni to Desvaux, his written comment with the name $A$. bertolonii Desv. and the reference to his book Amoenitates Italicae published in 1819 , suggest that it is later than the species description and therefore not original material.

= Alyssum bertolonii f. ramosum Nyár. in Bul. Gr囚d. Bot. Univ. Cluj 7: 100. 1928 ['1927'].

Locus classicus: 'Hab. Italia. Ferrato pr. Prato'. Type indication 'Hab. Italia. Ferrato pr. Prato; L. H. Groves (Herb. U. W., H. D.)'. Type not designated. 
Note. Duplicates of the original collection by $\mathrm{H}$. Groves are in E (E00438387, photo!) and K (K000484614, photo!).

\section{Description}

Suffruticose perennial, $15-45 \mathrm{~cm}$. Stems woody at base, herbaceous above, erect to ascending, with numerous basal sterile branches, more or less prostrate-diffuse and twisted. Indumentum of appressed stellate hairs with circular shape, c. $0.3 \mathrm{~mm}$ across, with c. 15 rays. Leaves of the basal sterile shoots oblanceolate-spathulate in shape, $1.5-3.5 \times 7-13 \mathrm{~mm}$, greyish above and canescent grey below for dense stellate hairs; leaves of the fertile stems usually longer and narrower than the basal ones, often abscissing after flowering and absent on fruiting stems. Inflorescence subcorymbose in the upper $1 / 3 \mathrm{c}$. of the fertile stems, with (1)2-6(7) lateral racemose branches elongating in fruit, bearing c. 10-40 flowers; secondary branches usually absent. Sepals c. $1.5 \mathrm{~mm}$, petals $2-3 \mathrm{~mm}$ yellow; stamen filaments appendaged. Fruit pedicels erecto-patent, $3.5-5 \mathrm{~mm}$ long at maturity; silicles $3.5-4.8 \times 2-2.7 \mathrm{~mm}$; narrowly elliptic-obovate, style c. $1.1 \mathrm{~mm}$; valves often with sparse stellate hairs $0.2 \mathrm{~mm}$ across, or completely glabrous. Seeds brown 1.9-2.1 $\times 1-1.2 \mathrm{~mm}$, wing absent or at most $0.1 \mathrm{~mm}$ wide. Flowering in June - July; fruiting in mid and late July.

Distribution. Liguria near Sarzana, Tuscany on all serpentine outcrops in the provinces of Firenze, Pisa, Livorno, Siena and Grosseto.

Chromosome number. $2 n=16$.

Odontarrhena bertolonii subsp. cesalpina Selvi, subsp. nov.; Figure 7.

Latin diagnosis. A typo habitu fruticosiore robustiore, caulis crassioribus, siliculae stilo longiore $(1.5-1.8 \mathrm{~mm})$, seminibus ala $0.2 \mathrm{~mm}$ lata in margine praeditis, numero cromosomico $2 n=32$ praecipue differt.

English diagnosis. Differs from the type mainly by the more robust, fruticose habit, the taller stems with thicker woody base, the longer style $(1.5-1.8 \mathrm{~mm})$, the seeds with wing $0.2 \mathrm{~mm}$ wide, the chromosome number $2 n=32$.

Holotype: Tuscany, Pieve Santo Stefano (Arezzo), Mt. Petroso, serpentine rocks and cliffs on steep $\mathrm{W}$-facing slopes, $43^{\circ} 38 \nabla 57 \rrbracket \mathrm{N}, 12^{\circ} 03 \rrbracket 22 \rrbracket \mathrm{E}, 450 \mathrm{~m}$ a.s.l, 24 Jun 2020, F. Selvi (Fl; isotype in FIAF, K, G).

Etymology. Named after Andrea Cesalpino, the first Italian botanist who described this plant in 1583 and understood its strict relationship with ultramafic soils ('in alia terra reperire non licet hanc herbam').

Chromosome number. $2 n=32$.

Distribution. Endemic to the ultramafic outcrops in the Upper Tiber valley in the Arezzo province, mainly in the municipalities of Anghiari and Pieve Santo Stefano: Monte Rognosi, Formole, Mt. Petroso, Mt. Murlo, Poggio delle Calbane, and other localities (Figure 1).

\section{Specimina visa (selecta)}

Alta Valle Tiberina, Poggio degli Scopeti, Versante Nord, Eufotide, 29 Jun 1937, R. Pichi Sermolli 8115, 8065 (FI); Alta
Valle Tiberina, M. Petroso, Ofiolite-serpentino, 25 Mai 1935, R. Pichi Sermolli 2721 (FI); Alta Valle Tiberina, Monte Petroso, versante Est, serpentino, 27 Jun 1937, R. Pichi Sermolli 8173 (FI); Alta Valle Tiberina, M. Murlo, serpentino, 2 Oct 1933, R. Pichi Sermolli 60 (FI); Alta Valle Tiberina, serpentini di Formole, Jun 1886, N. Cherici; Herb. Pichi Sermolli 3965 (FI); Montauto presso Arezzo, 26 Jun 1882, U. Martelli (FI); Alta Valle Tiberina, Montauto, 23 Mai 1995, A. Chiarugi, R. Corradi, O. Vergnano (FI); nelle rocce serpentinose Montenero a Pieve S. Stefano in Val Tiberina, Jun e Lug 1875, N. Cherici (FI); Mt. Auto presso Arezzo, Jun 1865, Marcucci (FI); Tra la Pieve San Stefano e le sorgenti del Tevere, roccia serpentinosa, 28 Jun 1885, S. Sommier (FI); Toscana, Mt. Rognosi d'Anghiari, sine die 1869, C.G. Siemoni (FI); Alta Valle Tiberina, Monte Petroso versante Ovest, serpentino, 23 Jun 1937, R. Pichi Sermolli 8058 (FI); Alta Valle Tiberina, M. Murlo, serpentino, 25 Jul 1932, R. Pichi Sermolli 62 (FI); Alta Valle Tiberina, M. Petroso, serpentino, 29 Nov 1934, R. Pichi Sermolli 1424 (FI); Alta Valle Tiberina, M. Murlo, serpentino, 8 Aug 1935, R. Pichi Sermolli (FI); Alta Val Tiberina, Pieve Santo Stefano (AR), affioramenti ofiolitici nella riserva statale Formole presso la riva s. del Tevere, 7 Sep 2011, L. Cecchi \& I. Colzi (FI); Alta Valle Tiberina, serpentini di M. Murlo, 8 Jun 1937, R. Pichi Sermolli 7187 (FI); Alta Valle Tiberina, Monte Petroso, versante Est, serpentino, 27 Jun 1937, R. Pichi Sermolli 8172, 8175 (FI); Alta Valle Tiberina, Monti Rognosi presso Albiano, serpentino, 13 Aug 1934, R. Pichi Sermolli 57 (FI); Alta Valle Tiberina, serpentini di M. Murlo, 29 Jul 1933, R. Pichi Sermolli 59 (FI); Alta Valle Tiberina, Poggio delle Calbane, 879 m, serpentino, 16 Jul 1937, R. Pichi Sermolli 7428 (FI); Pieve Santo Stefano alt. $700 \mathrm{~m}$, in serpentino, 6 Jun 1979, E. et S. Pignatti (FI).

\section{Acknowledgements}

The authors wish to thank Lorenzo Cecchi for discussion and assistance with the examination of herbarium material, Cristina Gonnelli for discussion of results and Isabella Bettarini for help during fieldwork.

\section{Disclosure statement}

No potential conflict of interest was reported by the author(s).

\section{Funding}

Funds from MUR and the research grants from the University of Firenze to FS are acknowledged.

\section{ORCID}

Federico Selvi (D) http://orcid.org/0000-0002-3820-125X

\section{References}

Arrigoni PV, Giannerini M, Mori B. 1980. Numeri cromosomici per la flora Italiana: 714-721. Inform Bot Ital. 12:137-143.

Arrigoni PV, Mori B. 1976. Numeri cromosomici per la flora Italiana: 270-275. Inform Bot Ital. 8:269-276. 
Bartolucci F, Peruzzi L, Galasso G, Albano A, Alessandrini A, Ardenghi NMG, Astuti G, Bacchetta G, Ballelli S, Banfi E, et al. 2018. An updated checklist of the vascular flora native to Italy. Plant Biosyst. 152(2):179-303.

Bettarini I, Colzi I, Gonnelli C, Pazzagli L, Reeves RD, Selvi F. 2020. Inability to accumulate $\mathrm{Ni}$ in a genus of hyperaccumulators: the paradox of Odontarrhena sibirica (Brassicaceae). Planta. 252(6):99.

Bretagnolle F, Thompson JD, Lumaret R. 1995. The influence of seed size variation on seed germination and seedling vigour in diploid and tetraploid Dactylis glomerata L. Ann Bot. 76(6):607-615.

Brooks RR, Radford CC. 1978. Nickel accumulation by European species of the genus Alyssum. Proc Roy Soc Lond B. 200:217-224.

Cecchi L, Bettarini I, Colzi I, Coppi A, Echevarria G, Pazzagli L, Bani A, Gonnelli C, Selvi F. 2018. The genus Odontarrhena (Brassicaceae) in Albania: taxonomy and nickel accumulation in a critical group of metallophytes from a major serpentine hot-spot. Phytotaxa. 351(1):1-28.

Cecchi L, Colzi I, Coppi A, Gonnelli C, Selvi F. 2013. Diversity and biogeography of Ni-hyperaccumulators of Alyssum section Odontarrhena (Brassicaceae) in the central western Mediterranean: evidence from karyology, morphology and DNA sequence data. Bot J Linn Soc. 173(2):269-289.

Cecchi L, Gabbrielli R, Arnetoli M, Gonnelli C, Hasko A, Selvi F. 2010. Evolutionary lineages of nickel hyperaccumulation and systematics in European Alysseae (Brassicaceae): evidence from nrDNA sequence data. Ann Bot. 106(5):751-767.

Cecchi L, Španiel S, Bianchi E, Coppi A, Gonnelli C, Selvi F. 2020. Odontarrhena stridii (Brassicaceae), a new nickel-hyperaccumulating species from mainland Greece. Plant Syst Evol. 306(4):69.

Cesalpino A. 1583. De Plantis libris XVI. Florentiae: Georgium Marescottum.

Chaussat R, Le Deunff Y. 1975. La germination des semences. Paris: Gauthier-Villars.

Chiarucci A. 2003. Vegetation ecology and conservation on Tuscan ultramafic soils. Bot Rev. 69(3):252-268.2.0.CO;2]

Chiarucci A, Foggi B, Selvi F. 1995. Garigue plant communities of ultramafic outcrops of Tuscany (Central Italy). Webbia. 49(2):179-192.

Coppi A, Baker AMJ, Bettarini I, Colzi I, Echevarria G, Pazzagli L, Gonnelli C, Selvi F. 2020. Population genetics of Odontarrhena (Brassicaceae) from Albania: the effects of anthropic habitat disturbance, soil, and altitude on a $\mathrm{Ni}$-hyperaccumulator plant group from a major serpentine hotspot. Plants. 9(12):1686

Corneillie S, De Storme N, Van Acker R, Fangel JU, De Bruyne M, De Rycke R, Geelen D, Willats WGT, Vanholme B, Boerjan W. 2019. Polyploidy affects plant growth and alters cell wall composition. Plant Physiol. 179(1):74-87.

Galardi F, Corrales I, Mengoni A, Pucci S, Barletti L, Barzanti R, Arnetoli M, Gabbrielli R, Gonnelli C. 2007. Intra-specific differences in nickel tolerance and accumulation in the Ni-hyperaccumulator Alyssum bertolonii. Environ Exp Bot. 60(3):377-384.

Godfree RC, Marshall DJ, Young AG, Miller CH, Mathews S. 2017. Empirical evidence of fixed and homeostatic patterns of polyploid advantage in a keystone grass exposed to drought and heat stress. R Soc Open Sci. 4(11):170934.

Hammer $\varnothing$, Harper DAT, Ryan PD. 2001. PAST: paleontological statistics software package for education and data analysis. Palaeontol Electron. 4:1-9.
Hopewell T, Selvi F, Ensikat HJ, Weigend M. 2021. Trichome biomineralization and soil chemistry in Brassicaceae from Mediterranean ultramafic and calcareous soils. Plants. 10(2):377.

Kidd PS, Bani A, Benizri E, Gonnelli C, Hazotte C, Kisser J, Konstantinou M, Kuppens T, Kyrkas D, Laubie B, et al. 2018. Developing sustainable agromining systems in agricultural ultramafic soils for nickel recovery. Front Environ Sci. 6:44.

Madlung A. 2013. Polyploidy and its effect on evolutionary success: old questions revisited with new tools. Heredity (Edinb). 110(2):99104.

Mengoni A, Gonnelli C, Brocchini E, Galardi F, Pucci S, Gabbrielli R, Bazzicalupo M. 2003. Chloroplast genetic diversity and biogeography in the serpentine endemic Ni-hyperaccumulator Alyssum bertolonii. New Phytol. 157(2):349-356.

Minguzzi C, Vergnano O. 1948. Il contenuto di nichel nelle ceneri di Alyssum bertolonii Desv. Atti Soc Tosc Sci Nat Mem Ser A. 55:49-77.

Morrison RR, Brooks RR, Reeves RD. 1980. Nickel uptake by Alyssum species. Plant Sci Lett. 17(4):451-457.

Nyárády EJ. 1928 (1927). Studiu preliminar asupra unor specii de Alyssum din sectia Odontarrhena. Vorstudium über einige Arten der Section Odontarrhena der Gattung Alyssum. Bul Grखd Bot Univ Cluj. 7(1-4):65160.

Pichi Sermolli REG. 1948. Flora e vegetazione delle serpentine e delle altre ofioliti dell'Alta valle del Tevere (Toscana). Webbia. 6:1-380.

Pignatti S. 2017-2019. Flora d'Italia. 2nd ed. Bologna: Edagricole.

Reeves RD, Brooks RR, Dudley TR. 1983. Uptake of nickel by species of Alyssum, Bornmuellera and other genera of Old World Tribus Alysseae. Taxon. 32(2):184-192.

Rešetnik I, Satovic Z, Schneeweiss GM, Liber Z. 2013. Phylogenetic relationships in Brassicaceae tribe Alysseae inferred from nuclear ribosomal and chloroplast DNA sequence data. Mol Phylogenet Evol. 69(3):772-786.

Robinson BH, Chiarucci A, Brooks RR, Petit D, Kirkman JH, Gregg PEH De Dominicis V. 1997. The nickel hyperaccumulator plant Alyssum bertolonii as a potential agent for phytoremediation and phytomining of nickel. J Geochem Explor. 59(2):75-86.

Sattler MC, Carvalho CR, Clarindo WR. 2016. The polyploidy and its key role in plant breeding. Planta. 243(2):281-296.

Selvi F. 2007. Diversity, geographic variation and conservation of the serpentine flora of Tuscany (Italy). Biodivers Conserv. 16(5):1423-1439.

Selvi F, Carrari E, Colzi I, Coppi A, Gonnelli C. 2017. Responses of serpentine plants to pine invasion: vegetation diversity and nickel accumulation in species with contrasting adaptive strategies. Sci Total Environ. 595:72-80.

Španiel S, Kempa M, Salmerón-Sánchez E, Fuertes-Aguilar J, Mota JF, Al-Shehbaz IA, German DA, Olšavská K, Šingliarová B, Zozomová-Lihová $J$, et al. 2015. AlyBase - database of names, chromosome numbers, and ploidy levels of Alysseae (Brassicaceae), with a new generic concept of the tribe. Plant Syst Evol. 301(10):2463-2491.

Stevens AV, Nicotra AB, Godfree RC, Guja LK. 2020. Polyploidy affects the seed, dormancy and seedling characteristics of a perennial grass, conferring an advantage in stressful climates. Plant Biol. 22(3):500513. 